\section{$1 \mathrm{P013}$}

\section{ペプチド及びタンパク質の低振動モードからみた水 分子の役割}

○山口 真理子、山本 晃司、谷 正彦、荻行 正憲（阪大レー ザー研)

これまでの非干渉性中性子散乱の测定から，タンパク質が活性化する $200230 \mathrm{~K}$ 以上では平均自乘変位が急激に増大し，非調和的な運動を 表す準弾性散乱が観測されることが報告されている. 脱水和したタン パク質はこのような温度変化を示さないことから，水分子がタンパク 質の機能発現に重要な役割を果たしていると考えられている。しかし 水分子がタンパク質のダイナミクスを変化させる詳細なメカニズムは 明らかになっていない，本研究は，タンパク質の機能発現における水 分子の役割を明らかにすることを目指している．そのためめ，マグ スコピックな視点でタンパク質の低振動モードの非調和性と水分量と の関伯を調べることにより，水分子が側鎖のゆらぎに与える影響をミ クロスコピックに理解していく必要がある，そこでまず，水分量の異 なるアラニンオリゴマーのテラヘルツ時間領域分光 (THz-TDS) の温 度㑈存性を測定し，テラヘルツ領域におけるバンド幅や連続吸収带の 温度変化から分子構造や分子配列の乱れを調べた. その結果，アラニ ンオリゴマーは水和によって低温での乱れが強く抑制されることが分 かった. 特にアラニン二量体では, $100 \mathrm{~K}$ 以下で数多く観測される分 子間振動に由来したバンドは，水和によってバンド幅が非常に小さく なる.これは乱れの抑制によって不均一幅が堿少したと考えられる。 一方 $100 \mathrm{~K}$ 以上では，水分子の有無に関係なくなだらかなスペクト ルになる.これは水分子が影響を与えないモードがあることを示して いる.これらの結果から水分子には，生体分子固有の振動や構造変化 などの動きを助ける役割があると考えられる．さらに，水分量の異な るニワトリ卵白リソチーム凍結乾燥粉末についても THz-TDS を行っ た. THz-TDS の測定結果と非干涉性非弾性中性子散乱の動的構造因 子との比較は当日に報告する.

M. Yamaguchi, K. Yamamoto, M. Tani, and M. Hangyo: The role of water molecules investigated from the low frequency modes of peptides and proteins

\section{$1 \mathrm{P} 015$}

\section{水核蛋白質のリピートト゚メインの立体構造}

O熊木 康裕 ${ }^{1}$ 、河野 敬一 ${ }^{2}$ 、松嶋 範男 ${ }^{3}\left({ }^{1}\right.$ 北大院 $\cdot$ 理 $\cdot N M R 、$

2 北大院 $\cdot$ 理 $\cdot$ 生物科学、 3 札幌医大・保健医療) 氷核活性細菌によって分泌される水核蛋白質は水の凍結を促進す る。この氷核蛋白質のアミノ酸配列は、中央部分に 48 残基の単位 配列が数十回繰り返したタンデムリピートをもつ。48 残基の単位 配列は、 16 残基および 8 残基の綝り返しと見ることもできる。こ のタンデムリピートが規則的な立体構造をとることで氷の結晶と相 互作用すると考えられている。しかしながら、その立体構造はいま だ明らかにされていない。本研究の目的は、このタンデムリピート の立体構造についての情報を得ることである。本研究では、Xanthomonas campestris pv. campestris str 由来の水核蛋白質のタンテ ムリピートの部分配列をモデルとした 17 残基からなるぺプチドAc$\mathrm{Q}^{1} \mathrm{~T}^{2} \mathrm{~A}^{3} \mathrm{R}^{4} \mathrm{~K}^{5} \mathrm{G}^{6} \mathrm{~S}^{7} \mathrm{D}^{8} \mathrm{~L}^{9} \mathrm{~T}^{10} \mathrm{~T}^{11} \mathrm{G}^{12} \mathrm{Y}^{13} \mathrm{G}^{14} \mathrm{~S}^{15} \mathrm{~T}^{16} \mathrm{~S}^{17}-\mathrm{NH}_{2}$ を合成し、そ の NMR 測定を行った。 NMR 解析の結果、 $\mathrm{A}^{3}$ と $\mathrm{L}^{9}$ のメチル基のプ ロトンは、 $\mathrm{Y}^{13}$ の芳香環プロトンとの間に NOE を示すことが明らか になった。このNMRの結果をもとに構造計算した結果、17残基のぺ プチドは全体として閉じたループ構造を形成することが示された。こ のループ構造でにおいて近接している Tyr の芳香環側鎖と Leu、Ala の側鎖メチル基との間の相互作用が、ループ構造の形成に寄与してい ることが強く示唆される。これらの残基は氷核蛋白質の一次構造にお いて保存性が高い残基であった。このことは、水核蛋白質のタンデム リピート全体がこのループ構造を単位とするラセン構造をとりうるこ とが示唆される。このループ構造を単位とするらせん構造モデを構 築し、氷核形成の機構を考察する。

\section{$1 \mathrm{P} 014$ \\ 異種及び同種 2 量体タンパク質の基準振動解析}

\author{
○猿渡 茂 ${ }^{1}$ 、輪湖 博 ${ }^{2}\left({ }^{1}\right.$ 北里大 $\cdot$ 理、 ${ }^{2}$ 早稲田大 - 社会科学)
}

タンパク質の機能は様々であるが、その根幹をなしているのは他の 分子との結合である。複数の分子からなるタンパク質複合体の基浲振 動解析を行い、各分子の重心間の相対位置が大きく変化するような基 準振動のモードが見つかれば、そのような基淮振動は複合体の解離 をうながすものである。しかし、逆に考えると複合体の形成反応に最 も強く関連している”結合モード”であるといえる。また、われわれ は、PDBに登録されたタンパク貿について逐次エネルギー極小化と 基準振動解析を実行してその結果を蓄積し、データベース ProMode を構築している ${ }^{[1]}$ 。現時点ではモノマー及び複合体中の各サブニニッ トについて計算を行っているが、将来的には複合体全体の解析結果も 登録する予定である。

本研究では、第一段階として、タンパク質 2 量体の系統的な基準振 動解析を行う。そのためには、PDBに登録されている複数鎖の系に ついてもシステマティックに一連の解析を行う必要があり、計算プロ グラムの自動化、種々の例外データへの対応を行った。異種 2 量体や 同種 2 量体でもPDBでの立体構造が異なっているものはこれまでと 同様に行えばよく、今までに数十個に対して解析を行った。結合モい ドの抽出は石田ら ${ }^{[2]}$ と同様に複合体中の 1 分子に対して Eckart 条件 を適用することにより行った。完全に対称的 (P2) な同種 2 量体に対 して対称な基準振動を得るためには、2 分子間の対称性を保持したま まエネルギー極小化計算を行うことが望ましいので、現在そのための 作業を進めている。また、複数鎖からなる系のダイナミクスを視覚的 に捉えることができるような表現方法の開発も行っており、学会では それらの結果について報告する予定である。

[1] Wako, Kato, \& Endo, Bioinformatics (2004) 20, 2035-43. [2] Ishida, Jochi, \& Kidera, Proteins (1998) 32, 324-33.

S.Endo and H.Wako : Normal mode analyses. of hetero and homo dimeric proteins

\section{$1 \mathrm{P} 016$}

\section{シチロウウオ由来 II 型不凍タンパク質のX線結晶構 造解析}

○西宮 佳志 ${ }^{1}$ 、杉本 宏 ${ }^{2}$ 、佐藤 涼子 ${ }^{1}$ 、野呂 奈津子 ${ }^{1}$ 、近藤

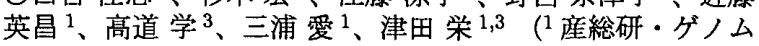
ファクトリー、2 理研・播磨、3 北大院・理)

不凍タンパク質 (AFP) は、氷結晶に結合しその成長を抑制する機 能を有したタンパク質の総称であり、極寒冷地に生息する生物が低温 もしくは涷結障害から生体を保護するために発現している。これま で、魚類、昆虫、バクテリア、植物等から一次構造の全く異なる様々 なAFPが発見・報告されており、これらのうち魚類由来I型、III 型 AFP そして昆虫由来 AFPは高分解能構造解析が行われ、水結晶結合 機序モデルが提唱されている。

1998 年、NMR 法を用いたケムシカジカ由来 II 型 AFP（srAFP）の 構造解析によって魚類由来 II 型 AFP が C 型レクチンの糖認識ドメイ ンに相同な構造を有することが明らかにされた。しかし、ループ領域 における主鎖構造の収束が十分でなく、また側鎖構造の久如により水 結晶結合機序に関する知見は未だ得られていない。我々は独自に国産 魚類由来 AFP を探索し、シチロウウオ (Longsnout poacher) 由来 II 型 AFP（lpAFP）の単離・精製および cDNAのクローニングに成功 した。そこで) Pichia pastoris を宿主とした lpÁFPの大量発現系を 構筑し、X線結晶構造解析を試みた。得られた結晶を用いて SPring-8 でデータ収集を行い、硫黄の異常分散を用いた SAD 法により位相を 決定した。その結果、 $1.34 \AA$ の分解能で lpAFP の構造が決定された。 IpAFPは $2 つ の ~ \alpha$ ヘックスと $8 つ の \beta$ ストランドからなり、NMR 法によって決定された srAFP と同一であった。現在、今回得られた lpAFP の立体構造から水結晶結合面を予想し複数種の変異体を作製 しており、各変異体の活性変化から II 型 AFP の水結晶結合面の検証 を行う予定である。

Y.Nishimiya, H.Sugimoto, R.Sato, N.Noro, H.Kondo, M.Takamichi A.Miura and S.Tsuda: X-ray crystal structure analysis of type II antifreeze protein from Longsnout poacher $\overline{\text { Y.Kumaki, K.Kawano and N.Matsushima : Structure of tandem re- }}$ peats within ice nucleation protein 